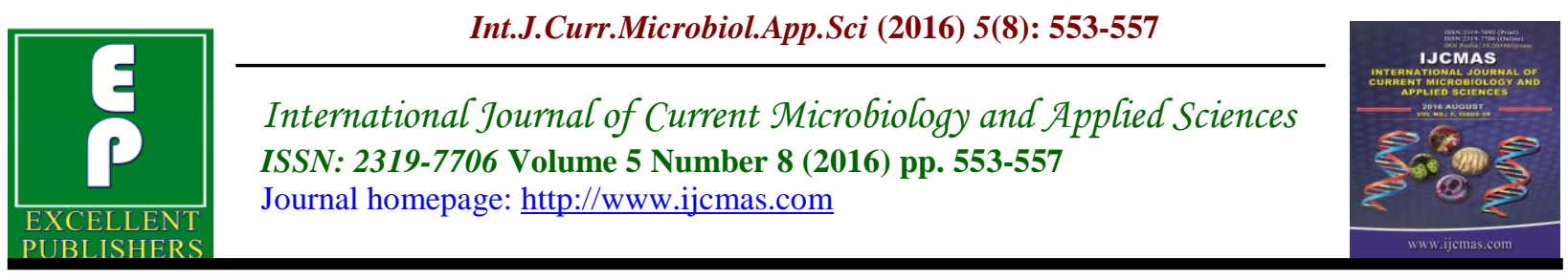

Original Research Article

http://dx.doi.org/10.20546/ijcmas.2016.508.060

\title{
Detection of Environmental Contaminants by RAPD Method
}

\author{
S. Pal* \\ Department of Botany, Lady Brabourne College, Kolkata, India \\ *Corresponding author
}

\begin{abstract}
A B S T R A C T
Keywords

RAPD, Genomic template stability, Biomarkar,

Cadmium, genotoxic.

\section{Article Info}

Accepted:

23 July 2016

Available Online:

10 August 2016

RAPD technique is already extensively used for species classification, genetic mapping and phylogenetic study. In addition, their use in surveying genomic DNA for evidence of various types of DNA damage and mutation shows that RAPDPCR may potentially constitute a biomarker assay for the detection of damage and mutational events in cell of bacteria, plants and animals. Being an effective investigation tool it is applied in genotoxicity, carcinogenesis studies and environmental toxicology research. Detection of genotoxic effects using RAPD involves the comparison of profiles generated from control and treated DNA. RAPD determines the genomic template stability which is related to level of DNA damage, so it helps in identification of various environmental pollutants with cytotoxic potential.
\end{abstract}

\section{Introduction}

Along with rapid urbanization and development of modern industry, soil polluted with heavy metals and various other contaminants has been identified in recent world. Impact assessment of contaminants in soil is important issue in environmental quality study and remediation of contaminated land. Among various heavy metals cadmium and chromium have immense uses in industries and produced in household wastes (MSW), so they have threatening impact on soil pollution. In recent years several plant species have been used as bioindicators of genotoxicity and various RAPD based (RFLP, RAPD, AFLP) tests have been developed to evaluate the toxicity of environmental contaminants
(Sava, 1998). The novel application of RAPD fingerprinting technique to detect genotoxin induced DNA damage to plant from contaminated sites is well practiced today (Liu et al., 2009). Genotoxicity describes a deleterious action on cell's genetic material affecting its integrity. This includes chemical compounds and certain types of radiations. These substances are all those with affinity to interact with DNA. Cd induces DNA damage such as single stranded, double stranded breaks, modified bases, abasic sites, DNA protein crosslinks, oxidized bases and bulky adducts (Atesi et al., 2004; Liu et al., 2009; Cencki et al., 2009). As genotoxicity of $\mathrm{Cd}$ is directly related to its effect on structure and function of DNA, it can be assayed or determined by 
a number of laboratory methods. But it is necessary to develop a reliable and reproducible genotoxicity assays which can be used in addition with traditional assays for detecting any impairment of population parameters (such as growth, reproduction and viability of offspring) due to heavy metal pollution of soil. Now RAPD has been successfully and extensively used as a sensitive and reliable method to detect $\mathrm{Cd}$ induced DNA damage such as mutational phenomenon, rearrangements, point mutation, small inserts or deletions of DNA and ploidy changes in cells of plant and animals and bacteria (Theodorakis et al., 2006; Shahratash et al., 2010). Some researches on DNA alterations in plants induced by soil contamination stress have been reported worldwide (Unyayar et al., 2006; Enan, 2006).

\section{Use of RAPD in genotoxicity and ecotoxicological study}

In recent years several plant species have been used as bioindicators and several tests have been developed to evaluate the toxicity of the environmental contaminants. Assessment of genotoxin induced DNA damage and mutation at molecular level is important in ecogenotoxicity study. In soil genotoxicity study, advances in molecular biology have led to the development of a number of selective and sensitive PCR based assay for DNA analysis. DNA alterations detected by RAPD analysis offered a useful biomarker assay for the evaluation of genotoxic effects of heavy metals in Capsicum annum (Aslam et al., 2014). Cd has the capacity not only to cause morbidity to the exposed organisms, but also has the potential to induce genotoxic effect has only established by RAPD (Cimino 2006; Theodorakis et al., 2006, Azimi et al., 2013). RAPD, one of the PCR based molecular marker techniques, is simple, rapid and low cost assay. The knowledge of genome is not required; in addition a single short random oligonucleotide primer is used. RAPD assay detects wide range of DNA damages (point mutations, inversions, deletions) and at the same time large number of samples can be studied. RAPD does not require radiolabelling for visualisation. In RAPD studies, similarities and diversities are described by appearance of new bands, disappearance of bands, and variation in band intensities. Ecotoxicological literature displayed that RAPD assay is a fundamental tool to evaluate the effects of toxicants on organisms under optimized conditions. The presence, absence and intensity of bands are related to DNA damages, mutations by genotoxicants. RAPD assay was successfully used to monitor DNA changes induced by heavy metals such as lead, cadmium, copper ( Körpe and Aras, 2011), UV and X-ray (Kuroda et al., 1999). DNA changes include damages and mutations that can be generated by toxicants directly and/or indirectly. According to RAPD profile, the genomic template stability (GTS \%) could be calculated as ' $100-(100(a / n))$ ' where ' $n$ ' is the number of bands in control RAPD profile and ' $a$ ' the average number of changes in sample profiles (Amina, 2012). GTS is related to the level of DNA damage, the efficiency of DNA repair and replication. DNA damages and mutations may alter a primer binding site and thus genomic template stability changes and polymorphism occurs within dosedependent treatments and untreated organisms. Erturk et al., (2013) established how DNA polymorphism and genomic template stability (GTS) value was significantly affected in $\mathrm{Cr}$ polluted maize seedling by RAPD. DNA damage in the root tip of maize seedling under $\mathrm{Cd}$ stress became evident by the presence and/or absence of DNA fragment in the treated samples compared to the control group was 
detected by RAPD analysis (Shahrtash et al., 2010). They have claimed that DNA polymorphism detected by RAPD can be considered as a useful tool, to detect environmental contaminants. In their work, Qurainy and his coworkers (2010) has reported that RAPD polymorphism can be utilized to detect genotoxicity of $\mathrm{Cd}, \mathrm{Pb}$ and $\mathrm{Zn}$ in Eruca sativa. Only three decamer primers used out of twenty gave single and polymorphic bands, but other 13 primers produced 5 bands. Multiple metal genotoxicity assessment showed same remarkable result in RAPD profile of Urtica dioica (Gjorgieva et al., 2013). DNA damage was detected by RAPD in Barley seedling treated with $\mathrm{Cd}$ (30-120 mg/L) (Liu et al., 2009). Their result showed variation in band intensity, loss of normal bands and appearance of new bands compared with normal seedling. Hydrilla verticillata and Ceratophyllum demersum treated with $10 \mu \mathrm{M} / \mathrm{L} \mathrm{Cd}$ showed change in chlorophyll content, protein content and DNA profile and DNA damage was investigated by RAPD analysis (Gupta et al., 2009). In their study Cenkci and his coworkers (2009) used RAPD to detect DNA damage in roots and leaves of Phaseolus vulgaris exposed to $\mathrm{Hg}$, $\mathrm{B}, \mathrm{Cr}$ and $\mathrm{Zn}$. They reported that polymorphism was evident by the appearances or disappearances of DNA bands in treated plant in comparison to the controlled ones. A study was conducted by Qari (2010) to investigate the genotoxic and antigenotoxic effect of aquous extract of Costus speciosus in the Allium cepa root tip. Through RAPD banding pattern antigenotoxic capacity of Costus speciosus extract was established. Enan (2006) studied the genotoxic potential of $\mathrm{Pb}, \mathrm{Cd}, \mathrm{Cu}$ and $\mathrm{Mn}$ on DNA integrity of kidney- bean applying RAPD technique and found distinct polymorphism between control and stressed plant. A total of 467 RAPD fragments in RAPD profiles were detected by using six random primers (decamers) and 224 of these fragments showed polymorphism. There was a distinct distance between the band patterns of treated plants and the control samples when the cluster method was applied. Genotoxic effect of different concentration of $\mathrm{Ni}$ and $\mathrm{Co}$ on maize studied by Erturk et al., (2012) revealed unique polymorphic band profile evident by appearances of new bands and decrease in genomic template stability with increasing concentration of metals. Soydam and his coworkers (2012) compared the effects of $\mathrm{Cu}$ and $\mathrm{Zn}$ treatments on root elongation, dry weight, total protein and changes in RAPD bands profiles of cucumber. Cumulative and antagonistic effects were observed between $\mathrm{Cu}$ and $\mathrm{Zn}$ contamination in terms of population parameter and RAPD band profiles. RAPD analysis can be applied as a suitable biomarker assay for the detection of genotoxic effects of plant allelochemicals and pharmacological products also. Racco et al., (2014) used RAPD successfully for molecular characterization of Dicentrarchus labrax embryonic cells (DLEC) as a tool to detect DNA alterations by pharmaceutical products in environmental toxicological study. Investigation of Kecek and his group (2012) revealed the genotoxic effect of the essential oils of catmint (Nepeta meyeri) against two weeds (Bromus danthoniae and Lactuca serriola) and two crop plants (Brassica napus and Zea mays) through RAPD. Genotoxic properties of essential oils extracted from dill (Anethum graveoleus) and fennel (Foeniculum vulgare) seeds were studied using RAPD on male rats (Alakilli, 2011). The use of Lichen as a bioindicator of environmental pollution has been established by Duman et al., (2011). They reported major variation in RAPD profile of Evernia prunastri exposed to the toxicity of polluted air smoke and waste discharge of iron steel factory. Aras 
and his coworkers (2011) studied the impact of environmental pollutants and heavy metal accumulation in lichen (Pseudovernia furfuracea) DNA through RAPD. Bozari and Aksakal (2012) evaluated the genotoxic potential of Trifluralin, a dinitroaniline herbicide on Zea mays by RAPD method and reported loss of normal bands and appearances of new bands in compare to control which was dose dependent. Over the last few years there has been a noticeable increase in studies aimed at evaluating the genotoxic effects of drugs through RAPD. Racco and his group (2011) studied the genetic alteration in Zebra fish (Danio rerio) exposed to Cabramazepine, a known antiepileptic agent and Diclofenac, a non steroid anti inflammatory drug through both RAPD and comet assay. The amplified product from the individuals showed significant changes in their electrophoretic pattern with respect to negative control. Results of the investigation of Abdelmigid (2009) indicated the DNA polymorphism detected by RAPD analysis could be a useful biomarkers assay for the detection of genotoxic effects of food dyes also.

It is concluded from all these studies that RAPD analysis could be a useful tool for quick detection of genotoxic effect of heavy metals, air pollutant, UV radiance, pharmaceutical molecules and herbicides in plants and comparison between treated and untreated genomes is necessary to evaluate how environmental pollutants modify the structure of DNA in living organisms.

\section{References}

Abdelmigid, H.M. 2009. Risk assessment of food coloring agents on DNA damage using RAPD markers. The Open Biotechnol. J., 3: 96-102.

Alakilli, S.Y.M. 2011. Investigation of genetic toxicology of Dill and Fennel extracts and cyclophosphamide in male rats by RAPD-
PCR assay. J. America. Sci., 7(9): 398408.

Amina, A., Aly. 2012. Application of DNA (RAPD) and ultrastructure to detect the effect of Cd stress in Egyptian clover and Sudan grass. J. Stress Phy. Bio., 8: 241257.

Aras, S., Beyaztas, T., Duman, C., Gunduzer, G. 2011. Evaluation of genotoxicity of Pseudovernia furfuracea (L.) Zopf. By RAPD analysis. Genetic Mol. Res., 10(4): 3760-3770.

Aslam, R., Ansari, M.Y.K., Choudhary, S., Bhat, T.M. and Jahan, N. 2014. Genotoxic effects of heavy metal cadmium on growth, biochemical, cyto-physiological parameters and detection of DNA polymorphism by RAPD in Capsicum annuиm L.- an important spice crop in India. Saudi J. Bio. Sci., 21: 465- 472.

Atesi, I., Suzen, H.S., Aydin, A., Karakaya, A. 2004. The oxidative DNA base damage in tests of rats after intra peritoneal cadmium injection. Biometals, 17: 371-377.

Azimi, A., Shahriari, F., Fotovat, A., Qale, R.K., Agje, K. 2013. Investigation of DNA changes in wheat (Triticum aestivum L.) induced by cadmium using RAPD analysis. Afr. J. Biotech., 12(16): 19211929.

Bozari, S., and Aksakal, O. 2012. Application of RAPD to detect genotoxic effect of trifluran on maize (Zea mays). Drug. Chem. Toxicol., 61: 379-381.

Cenkci, S., Yildiz, M., Cigerci, I., Konuk, M., Bozdag, A. 2009. Toxic chemical induced genotoxicity detected by random amplified polymorphic DNA (RAPD) in bean (Phaseolus vulgaris) seedlings. Chemosphere, 76: 900-906.

Cimino, M.C. 2006. Comparative overview of current international strategies and guidelines for genetic toxicology testing for regulatory process. Environ. Mol. Mutagen 47: 362-390.

Duman, D.C., Atakol, O., Aras, S. 2011. Assessment of air pollution genotoxicity by RAPD in Evernia prunastri L. Arch. From around iron steel factory in Karabuk, Turkey. J. Environ Sci., 23(7): 1171-1178. 
Enan, M.R. 2006. Application of random amplified polymorphic DNA (RAPD) to detect the genotoxic effect of heavy metals. Biotechnol. Appl. Biochem., 43: 147-154.

Erturk, F.A., Agar, G., Nardemir, G., Arslan, E., Bozari, S. 2013. Genetic changes in maize seedlings induced by chromium pollution using RAPD analysis. Proc. of ICOEST, 18-21.

Erturk, F.A., Nardemir, H.A.G., Agar, G. 2012. Molecular determination of genotoxic effect of Co and $\mathrm{Ni}$ on maize (Zea mays) by RAPD and protein analysis. Toxicol. Ind. Health, 13: 141-153.

Gjorgieva, D., Tatjana , K.P., Tatjana, R., Katerina, B. 2013. Influence of heavy metal stress on Antioxidant status and DNA damage in Urtica dioica. Biomed. Res. Int.

Gupta, M., Sarin, N.B. 2009. Heavy metals induced DNA changes in aquatic macrophytes: Random amplified polymorphism DNA analysis and identification of sequence characterized amplified region marker. J. Environ. Sci., 21: 686-690.

Kekec, G., Muthi, S., Alpsoy, L., Sakcali, M.S., Atici, O. 2012. Genotoxic effect of catmint (Nepeta meyeri Benth) essential oils on some weed and crop plants. Toxicol. Ind. Health., 28(6).

Korpe, D.A. Aras, S. 2011. Evaluation of $\mathrm{Cu}$ induced stress on eggplant (Solanum melongena L.) seedlings at the molecular and population levels by use of various biomarkers. Mut. Res., 719(2): 29-34.

Kuroda, S., Yano, H., Koga-Ban, Y., Tabei, Y., Takaiwa, F., Kayano, T., Tanaka, H. 1999. Identification of DNA polymorphism induced by X-ray and UV irradiation in plant cells. Japan Agri. Res. Quarterly, 33: 223-226.

Liu, W., Yang, Y.S., L,P. J., Zhou, Q. X., Xie, L. J. Han, Y.P. 2009. Risk assessment of cadmium contaminated soil on plant DNA damage using RAPD and physiological indices. J. Haza. Materials, 161: 878-883.

Qari, S.H. 2010. DNA-RAPD fingerprinting and cytogenetic screening of genotoxic and antigenotoxic effect of aqueous extracts of Costus speciosus (Koen). JKAU Sci., 22: 133-152.

Qurainy, F., Alameri, A.A., Khan, S. 2010. RAPD profile for the assessment of genotoxicity on a medicinal plant: Eruca sativa. J. Med. Plants Res., 4(7): 579-586.

Racco, L., Valentino, I.V., Scapigliati, G., Stingo, V. 2014. RAPD-PCR analysis for molecular characterization and genotoxic studies of a new marine fish cell line derived from Dicentratchus labrax. Cytotechnol., 66: 383-393.

Savva, D. 1998. Use of DNA fingerprinting to detect genotoxic effect. Ecotoxicol. Environ. Safety, 41: 103-106.

Shahrtash, M., Zaden, S.M., Mohabatkar, H. 2010. Cd induced genotoxicity detected by the random amplification of polymorphism DNA in the maize seedling root. J. Cell and Mol. Res., 2(1): 42-48.

Soydam, A.S., Gokec, E., Buyuk, I., Aras, S. 2012. Characterization of copper and zinc induced stress on Cucumber (Cucumis sativus) by molecular and population parameters. Mut. Res., 746(1): 49-55.

Theodorakis, C.W, Lee, K.L., Admas, S.M., Law, C.B. 2006. Evidence of altered gene flow, mutation rate and genetic diversity in redbreast sunfish from a pulpmill contaminated river. Environ. Sci. Technol., 40: 377-386.

\section{How to cite this article:}

Pal, S., 2016. Detection of Environmental Contaminants by RAPD Method. Int.J.Curr.Microbiol.App.Sci. 5(8): 553-557. doi: http://dx.doi.org/10.20546/ijcmas.2016.508.060 